\title{
Analysis on the Internal Connection of the Network Culture and the Ideological and Political Education
}

\author{
Caixia HU, Yayang TANG \\ College of Marxism, Hunan University, Changsha, China
}

\begin{abstract}
Network culture has the function of ideological and political education, and ideological and political education has cultural connotations. Network culture and ideological and political education are internal fit. Firstly, Network culture enlightening people fits ideological and political education educating people. Secondly, the operational process of the network culture fits the implementation process of the ideological and political education. Thirdly, the universality of the network culture fits the extensiveness of the ideological and political education. In addition, the spread of the network culture fits the publicity of the ideological and political education. Therefore, we must adhere to combine integrity of ideological and political education with fragments of network culture, combine political nature of ideological and political education with civilian nature of network culture, combine dominant nature of ideological and political education with multiple properties of network culture, to help ideological and political education and network culture to connect and interact with each other.
\end{abstract}

KEYWORD: Network culture; ideological and political education; internal connection.

\section{INTRODUCTION}

With the development and popularity of the network in our country, some western politicians excitedly claimed that "with the Internet, there is a way to deal with China "," The socialist countries into the arms of the west will start from the Internet". Facing the severe situation of network, Xi Jin ping stressed in the national publicity and ideological work conference in 2013 that the Internet has become a key battleground in the struggle of public opinion and we should regard the Internet public opinion propaganda as a priority task in ideological work. It seems China's high consciousness to construction of network culture and accurate comprehension of the ideological and political education. However, really good use of network culture to carry out ideological and political education and establishment of a new network position of ideological and political education need to fully understand and grasp the internal connection of the network culture and the ideological and political education. This paper, on the basis of clarifying the function of ideological and political education in network culture and the cultural property in ideological and political education, is mainly to discuss the depth fit and positive interaction between them.

\section{IDEOLOGICAL AND POLITICAL EDUCATION FUNCTION OF NETWORK CULTURE}

\subsection{Internet culture shaping people's moral concepts through penetration mechanism}

Currently, the network culture has not only become an important educational resource, given the ideological and political education entirely new means; but also carries the human's thought and development ability, and has shaped systematic cultural model and cultural habits to regulate individuals values and behavior in a certain and unconscious and normalized pattern. On the one hand, the social spirit condensed in the product of network culture will influence people's ideological and moral concepts, and association rules and behaviors in the network culture environment tend to standardize and guide the internet users' network behavior. On the other hand, network culture makes the content of ideological and political education visualized and specific through a variety of ways, so as to attract people of different levels. People accepting a certain network culture means the recognition to the social norms and behaviors so as to enhance the education function of internet culture. 


\subsection{Network culture integrating people ideological and moral idea through coherency function}

Any kind of culture is the product of human activity in a particular era, reflecting the unique cultural and social reality factor. network culture is not exception, which will bring certain social thoughts and objects into corresponding cultural form, thus network cultural products with obvious social features reflect the social requirement. At present China advocates guiding the network culture construction with the socialist core value system, and actively promotes the network main melody to construct positive and healthy network culture environment. On the other hand, people in the face of social stimulation will produce similar reflection. For example, what is disdained by culture might be denied by the public, and what is pursued might be affirmed by the masses. Therefore, the psychological mechanism of culture, coupled with China positively guiding network culture construction, largely helps the social members to accept the social mainstream values and form common values, ideals and beliefs.

\subsection{Network culture building a new environment of ideological and political education}

Ideological and political education is the social educational practice activity, and its effect is closely related to social environment. Only the teaching content of ideological and political education is consistent with social reality, people are more willing to believe, accept and recognition. Network culture doesn't appear naturally, which is the product of human creation and is the object for people to share, use and reproduce. Besides, network culture has duality which makes it with positive and negative impact on people. If the network culture environment is contrary to the content of ideological and political education, then ideas and norms of ideological and political education are difficult for people to accept and internalize into individual consciousness, thus leading to social belief crisis, impacting ideology safety. Therefore, according to social demands and educational purposes we should actively design and transform local network culture environment. We can carry out active activities, promote the socialist advanced culture and advanced deeds of reflect the spirit of the time and criticize the social bad phenomenon and ethos in the network so as to form a strong positive "public opinion", create a new position to meet the social members' development and increase the attractiveness and influence of ideological and political education.

\section{CULTURE PROPERTY OF IDEOLOGICAL AND POLITICAL EDUCATION}

\subsection{Ideological and political education is a kind of cultural forces}

Cultural force is the cultural nature of the ideological and political education, and is a positive force to promote the development of individual and society. On the other hand, cultural force is the concentrated reflection of the tool rationality and the tool value of the ideological and political education, and is the "force" which plays a great role in man's thought through ideological and political education. Ideological and political education must have this cultural force in order to regulate and standardize the personal thoughts and behavior, to promote ideological and moral construction, to become a spiritual power of individual behavior and to enhance social and cultural cohesion.

\subsection{Ideological and political education is the practice activity of cultural reproduction}

Ideological and political education is the education practice which is based on "educational goals "and "education carrier" to spread "educational content ". Among them, the educational goals are set according to social and cultural impact, the requirements of social development and spiritual and cultural needs of learners, which reflect the core values of social culture. Then, education carrier, such as teaching, discussing and literary works, in the end is also decided by social and cultural conditions, and culture is the important carrier of ideological and political education. In addition, the educational content, such as political culture, ideology, morality, and psychological quality, is an important part of social culture.

\subsection{Ideological and political education is the process of cultural integration and innovation}

On the one hand, Ideological and political education actively develops the ideological and moral factors in the cultural products and actively penetrates the education content into cultural activities to exert a subtle influence on people. On the other hand, ideological and political education according to the social and cultural requirements selects cultural factor consistent with its own purposes to integrate and condense into the social mainstream ideology in order to spread to the audience and thus form a common community values. At the same time, the spread of the ideological and political education is not to repeat the mainstream culture and one-way infusion, but is the interactive, inheriting and updating process for cultural factors. In addition, the ideological and political education should not only adhere to the Marxist ideology, but also have to face 
new situations and new problems to innovate culture from content, methods and other aspects.

\section{NETWORK CULTURE AND IDEOLOGICAL AND POLITICAL EDUCATION DEPTH FIT}

\subsection{Network culture enlightening people fits ideological and political education educating people}

Network culture subtly affects people's moral values through a variety of styles. Meanwhile, the network culture will enlighten different values of the people. Therefore, in order to ensure that the people are oriented in the right direction, China advocates with the socialist core value system to lead the network culture, advocates to arm people with a healthy network culture, advocate to guide and shape the people to sing the main theme of the Internet to form a common ideals and beliefs and morality concepts. Ideological and political education is itself a cultural activity, and it in the final analysis is to explore ways to cultivate people. Therefore, advancing network culture educated function and the educated function of ideological and political education have natural similarities.

\subsection{Operational process of network culture fits implementation process of ideological and political education}

On the one hand, the network culture is the social and cultural activities formed in cyberspace, and the final destination is to promote human development. Ideological and political education is about people's education, and the ultimate goal is to improve people's moral and cultural qualities. On the other hand, the socialist core value system is the important content of ideological and political education, is the soul of an advanced socialist culture, and is the essence of the culture construction. In addition, the impact of network culture on people is growing, so we could hold extensive and active and healthy internet culture activities which are penetrated into the content of ideological and political education, so that the audience unknowingly accept the ideological and political education.

\subsection{Universality of network culture fits extensiveness of ideological and political education}

Today, network culture has widely existed in many areas of social life and has a profound impact on all walks of people's lives and development, and considered the network as partner has become a common way of life to modern people. Xi Jin ping stressed in the national publicity and ideological work conference in 2013 that propaganda and ideological work is a man's job and should focus on where people are staying. Visibly, anywhere and any unit people need to accept the ideological and political education, which is open to all members of society with a wide range of masses. The universality of network culture provides conditions for ideological and political education covering all the social members.

\subsection{The spread of network culture fits the publicity of ideological and political education}

Internet as a new form of public dissemination has a significant spread function. Ideological and political education is the activity with educator spreading ideas of social morality society needs to the educated. Marx and Engels put forward the concept of "publicity" very early, so propaganda is an inherent property of the ideological and political education. Network world is a vacuum environment, which is soon filled with colorfully bad information if advanced culture do not occupy it. The most important task of network culture is to occupy the network position actively in order to convey the voice of the party and the government durably and widely and to spread Marxist theory and its latest achievements and the party's principles and policies, so as to improve people's spiritual, cultural, ideological and moral level. On the other hand, network culture timely spread advanced times spirit and times features fresh to help people increase knowledge, widen horizon and enrich life, and to complete important mission of promoting people's all-round development through the process of socialization of people in the ideological and political education.

\section{THE INTERACTION OF IDEOLOGICAL AND POLITICAL EDUCATION AND NETWORK CULTURE}

\subsection{Combine integrity of ideological and political education with fragments of network culture}

Ideological and political education environment is the education field created by educator and the educated mutual induction and the two-way interaction. Internet culture gives new cultural environment for ideological and political education and affects the content, methods and effects of education. Ideological and political education stresses on comprehensively grasping and practicing the education content rather than vice versa. In network culture environment, people are more favor of limited, piecemeal and fragmented content, loved with fast and shallow reading type, hated to "packaging" information after the traditional authority media, so the ideological and political education needs to cater to the students' needs and 
preferences, cultivates healthy environment and consciousness of network culture, highly summarizes some education idea and requirements, and builds up the idea of "propaganda" to make the ideas appeared of high frequency in the network position for a long time.

\subsection{Combine political nature of ideological and political education with civilian nature of network culture}

Ideological and political education is educational practice activity to maintain the dominance of a certain class. Over the years the communist party of China is more political importance of ideological and political education. However, some of the education content is too vague and impractical for the masses to accept and recognize. Network culture emphasizes the civilian nature, and users can spread their thoughts, record their lives, and discuss the common topic. With the popularity of the network, the process of ideological and political education need to strengthen human spirit penetration, and emphasize spirit and emotion to educate people; educational content need to be transformed into little common sense which is closed to practice and life, making people feel the charm of mainstream values so as to strengthen affinity and effectiveness of ideological and political education.

\subsection{Combine dominant nature of ideological and political education with multiple properties of network culture}

In the Internet, the information of the ideological and political education is among the inclusions of the mass information which will increase pressure on people's choice. Besides, negative news in network impact people's values. In addition, in the network high freedom and diverse entertainment and leisure let college students indulge easily and so on. Therefore, constructing network culture needs the ideological and political education to advocate the primary culture, lead the subculture, and restrain counter culture. On the other hand, under the network environment, accepting or rejecting the information entirely depends on Internet users' needs and faith, and are not like traditional ideological and political education with intervention by educators teaching face to face, so faced with diverse forms of network culture, we need the guidance of the ideological and political education to ensure correct orientation.

\section{REFERENCES}

[1] Zheng Yongting. Ideological and political education methodology. Beijing: Higher Education Press, 2010,12.

[2] Chen Wanbai, Zhang Yaocan. Ideological and political education principle. Beijing: Higher Education Press, 2007.7.

[3] Shen Zhuanghai. Culture vision of ideological and political education. Beijing: People's Publishing House, 2005.9.

[4] Song Yuanlin, Chen Chunping. Network culture and ideological and political education of university students. Changsha: Hunan People's Publishing House, 2006.4.

[5] Zhu Zhigang. The theory of the cultural integration function of ideological and political education. Theory Journal, 2007.11.

[6] Zhang Pengzhi. The internal relations of socialist core values and the Chinese dream. Guangming Daily, 2013.4.

[7] Li Xingxuan. The challenge and innovation of network ideological and political education. Study of Ideological and Political Work, 2014.7. 